\title{
ARTES
}

\section{CAROLINA MARIA DE JESUS}

\section{Cristóvão José dos Santos Júnior}

Universidade Federal da Bahia (UFBA), Brasil

cristovao_jsjb@hotmail.com

DOI: https://doi.org/10.26512/caleidoscopio.v4i1.31748

Recebido em: 24/05/2020

Aceito em: 04/07/2020

Publicado em dezembro de 2020

O Canindé já tem sua Heroína,

que carrega a brasa da Resistência na caneta,

imortal de uma chama que convoca nossa Consciência,

residindo na potência de uma escrita viva.

No Despejo ou na Alvenaria, ela se conjuga

aos lamentos, prantos e gritos Insubmissos

que atravessam gerações em ecos Ancestrais, repletos de Dor, Temor e Luta.

Na Solitude de sonhos e esperança,

Ela produz uma arte protagonista de si e de todos.

Fundante de impulsionamentos que traspassam até a Fome,

Ela percorre caminhos Dissidentes de uma glória

que imprime rasuras que me atravessam

e falam com nossos pais, irmãos e filhos,

tensionando, em rica Poética, a própria língua!...

\section{Biografia do autor}

Cristóvão José dos Santos Júnior é classicista, medievalista, jurista e poeta. É doutorando e mestre em Literatura e Cultura pela Universidade Federal da Bahia (UFBA). Atualmente, dedica-se ao desenvolvimento de duas traduções, uma lipogramática e outra alipogramática, até então inéditas em língua portuguesa, da De aetatibus mundi et hominis, atribuída ao autor africano e tardo-antigo Fulgêncio, o Mitógrafo. 